\title{
Fundamentals of the Real Estate Legislative System and Its Impact on Sustainable Development: Dubai Case Study
}

\author{
Iyad Mohammed Jadalhaq
}

Abu Dhabi University, Abu Dhabi, United Arab Emirates

\begin{abstract}
The real estate legislative system is one of the bases of the sustainable development process. This research focuses on the role of the legal system in sustainable development, according to the most prominent relevant international reports. The UAE ranked forty-first globally in the Human Development Index (HDI). In the World Bank's 'Doing Business Report', the UAE ranked second globally and first in the Middle East and North Africa (MENA) for the 'Dealing with Construction Permits' indicator. Thus, the Emirate of Dubai is deemed the second-best city in the world in terms of ease of dealing with construction permits. For the 'Registering Property' indicator, the UAE ranked tenth globally and first in the Middle East and North Africa (MENA). Despite the UAE's great achievements in terms of developmental ranking at the global level, there is still more to achieve in the field of development.
\end{abstract}

\section{Keywords}

real estate - property registration - developers - escrow accounts - UAE Development Indicators - sustainable development

\section{Introduction}

Achieving sustainable development is a matter of great global interest. ${ }^{1}$ Most countries have become aware of the importance of sustainable development,

1 Sustainable development is development that meets the needs of the present without putting at risk the ability of future generations to satisfy their needs. It focuses on sustainable 
both for the present and for the future. Since its inception, the United Arab Emirates (UAE) has attached great importance to the economic, social and legal measures needed to achieve sustainable development. It has established several government institutions and bodies specialized in conducting and setting studies, mechanisms and programmes to help achieve sustainable development. The strategic management of the UAE pays close attention to the significance of legislating for real estate activities to complete the matrix of measures required for achieving sustainable development. The UAE's federal legislators have enacted several laws that regulate ownership of real property. Furthermore, the Emirate of Dubai (Dubai) has issued many laws and regulations that govern the right to property for citizens and foreigners, the activities of real estate developers and brokers, property registration and transfer, tenancy and other areas for the purpose of encouraging investment in real estate activities, all of which contribute to achieving sustainable development.

Real estate legislation, and government measures and regulations relating to the licencing and activities of businesses in any economy, are among the most significant variables influencing economic growth and, in general, macroeconomic indicators. Furthermore, they play a crucial role in the country's investment climate, as well as in attracting leading projects. Hence the activities of the private sector in the country, and the dynamism and effectiveness of the sector's role in the economy, are significantly affected by the procedures and regulations governing business activities-including those regulating property rights and property rental (as well as by business costs, in terms of the fees and expenses to be borne by a business for procuring a certain activity licence, especially for small to medium-sized enterprises, or SMEs). This study explores the real estate legislative system in Dubai-the UAE's economic capital — and its impact on sustainable development. Thus, the significance of this research is embedded in its focus on one of the most notable factors for achieving sustainable development - the real estate legal system.

The study relies on the analytical-descriptive approach to explore the impact of real estate legislation, which regulates property rights and all other

economic growth, environmental stewardship and social responsibility. As mentioned at the forefront of the Declaration on the Right to Development (4 December 1986), development is defined as 'a comprehensive economic, social, cultural and political process, which aims at the constant improvement of the well-being of the entire population and of all individuals, on the basis of their active, free and meaningful participation in development and in the fair distribution of benefits resulting therefrom'. For more details, see Salem Khadim AlDhanhani, Sustainable Development in the United Arab Emirates, 3rd ed. (Abu Dhabi: The Ministry of Culture, 2011), 10. 
relevant themes in the UAE's sustainable development indicators. It does so by tracing the rankings of the UAE in various major global development indicators, most notably the Human Development Index (HDI) of the UNDP's 'Human Development Report' and the Ease of Doing Business Index of the World Bank's 'Doing Business Report'.

\section{$2 \quad$ Federal Legislation}

The right to property is one of the most powerful and far-reaching original rights in rem. It entitles its holder to all powers, including use, exploitation and disposition. ${ }^{2}$ UAE legislators have defined the right to property as 'the authority of the owner to dispose of his property in an absolute, real, beneficial and useful manner. ${ }^{3}$ Therefore, the right to property is a direct authority of a certain person over a certain item, enabling him to use, exploit and dispose of it within the limits of the law. ${ }^{4}$

UAE legislators have been keen to regulate the ownership of real property, under the federal laws applicable to all the emirates, including Dubai. ${ }^{5}$ Principal among these laws is the Constitution of the United Arab Emirates (1971), according to which private property is protected, and no one can be deprived of their private property, except in circumstances dictated by the public benefit, in accordance with the provisions of the law and on payment of fair compensation. Public confiscation of property is prohibited, and a person's

2 Hasan Kera, Introduction to Law (Alexandria: Monchaat Al-Maaref, 1993), 193.

3 Law on Civil Transactions, Art. 1133.

4 Ali Hadi Al-Obeidi, The Original Rights in Rem According to the Civil Transactions Law of the United Arab Emirates (Abu Dhabi: Al-Afaq Al-Moushrika, 2011), 21.

5 The study focuses on major legislation relating to the ownership of property. However, many UAE federal laws are concerned with achieving sustainable development, including: Law No. 23 of 1999, Concerning Exploitation, Protection and Development of the Living Aquatic Resources; Law No. 24 of 1999, Concerning Environment Protection and Development; Law No. 1 of 2002, Concerning Regulation and Control of the Use of Radioactive Sources and Protection against Its Hazards; and Law No. 11 of 2002, Concerning Regulation and Control of International Trade of Endangered Animals and Plants. In addition, the Federal National Council (FNC) issued many regulations in 2001 in that regard, including: Regulations on Marine Environment Protection; Regulations on Handling of Hazardous Materials and Waste and Medical Waste; Regulations on Environmental Impact Assessment (EIA) for Facilities; and Regulations on Pesticides and Fertilizers. For more details, see Nawzad Abdulrahman AlHiti, Sustainable Development: General Framework and Practices:The UAE Model (Abu Dhabi: The Emirates Center for Strategic Studies and Research, 2009), 124 et seq. 
private property may not be confiscated, except by court judgment. The Constitution further confirms that the national economy shall be grounded on social justice and faithful cooperation between public and private activities, and shall seek to achieve economic development, increase productivity, raise standards of living and achieve prosperity for its citizens. It grants foreigners the rights and freedoms stipulated in international instruments, as well as in treaties and conventions. ${ }^{6}$

As one of the original rights in rem, the right to property is regulated. ${ }^{7}$ Owners are granted rights to use, exploit and dispose of their property and to take all legal actions. Land ownership is deemed to include that which is above and below, as far as it can be usefully enjoyed in height and depth. No one can be deprived of their property without lawful reasons, and owners must be fairly compensated in the event their property is expropriated. ${ }^{8}$ Certain provisions regulate common ownership and restrict ownership, within an accurate legal framework. Ownership of stores and departments is also regulated, and certain shared parts are deemed to be owned in common among occupants of a given building. It further lists the reasons for owning a property, requiring that for an acquisitive prescription to be valid, the property under possession must not be registered with the Land Department; if it is, no person may acquire it by means of seizure. ${ }^{9}$

\section{3}

\section{Local Legislation in Dubai}

The right to property has a social function. Certain things that may be privately owned and others that are prohibited are specified by law. It further determines the amount that may be owned for the public interest. ${ }^{10}$ The right to real property is the one most related to the social function of the right to property in general, as real properties represent a high value and, hence, their ownership is linked to the national economy and is made in conformity with the economic and developmental policies approved by the state. UAE legislators have

6 See the Constitution of the United Arab Emirates, Arts. 21, 39, 24 and 40.

7 Law No. 5 of 1985 , on Civil Transactions.

8 Expropriation of private property is made for public benefit, including establishing, expanding or improving roads, streets and squares; establishing new neighbourhoods or water, sanitation and energy projects; and establishing bridges and tunnels. Eid Saad Desouki, Protection of Private Property in the Administrative and Constitutional Judiciaries Comparative Study (Cairo: Al-Nahda Al-Arabeya, 2012), 149.

9 See the Law of Civil Transactions, Arts. 1133, 1134, 1136 et seq., 1188 et seq., and 1317.

10 Mohammed Al-Moursi Zahra, The Original Rights in Rem in the Federal Civil Transactions Law (Abu Dhabi: Publications of the United Arab Emirates University, 1999), 85. 
defined real property as anything that is settled and fixed in space and cannot be moved without deterioration or alteration of its shape. ${ }^{11}$ Accordingly, real property includes land, buildings, facilities, and so forth. ${ }^{12}$

Many laws have been issued in Dubai to regulate the ownership of real property. This follows a clear vision to position Dubai as the world's top real estate destination in terms of innovation, trust and happiness. It follows a mission to create an innovative and sustainable real estate environment that will promote Dubai as the world's happiest city, through smart services, financial, human and professional resources, and integrated real estate legislation. ${ }^{13}$

\subsection{Granting of Right to Real Property to Non-UAE Nationals}

Non-UAE nationals have the right to acquire freehold ownership rights over real property, without time restriction, usufruct rights or leasehold rights, for up to ninety-nine years with respect to land plots located in twenty-three listed investment zones. ${ }^{14}$ The UAE legislators have not followed legislators in many other countries, who have either prohibited non-citizens from owning real property or granted them a limited right to do so. There is no doubt about the importance of this step taken by the UAE legislators, which comes in the context of strategic planning for sustainable development. Granting the right of ownership to non-UAE nationals will encourage them to invest in real estate. This will benefit the national economy and achieve sustainable development by creating new areas of investment, which will secure new resources for future generations. The flexibility in real estate legislation will serve to create new opportunities for sustainable development.

\subsection{Granting of Title to Allotted Industrial and Commercial Lands}

Decree no. (4) of 2010, Regulating the Granting of Title to Allotted Industrial and Commercial Lands in the Emirate of Dubai, entitles a UAE-national, to whom the land is allotted, to apply to the Land Department for the freehold of that land, without any restriction on its use, exploitation or disposition. ${ }^{15}$ The department considers the application, in coordination with other concerned

\footnotetext{
11 Law on Civil Transactions, Art. 101.

12 Abdulrazzak Al-Sanhouri, The Intermediate Book on the Explanation of the New Civil Code (8) The Right to Property, 3rd ed. (Cairo: Nahdet Misr, 2011), 20.

13 See the Land Department's website at www.dubailand.gov.ae/Arabic/about/aboutdld, accessed 10 June 2016.

14 Regulation No. 3 of 2006, Determining Areas for Ownership by Non-UAE Nationals of Real Property in the Emirate of Dubai, Arts. 3 and 4.

15 Decree No. 4 of 2010, Regulating the Granting of Title to Allotted Industrial and Commercial Lands in the Emirate of Dubai.
} 
entities in the emirate. If it approves the application, it grants the beneficiary title to the allotted land, registers the land in their name in the property register and issues the title deed, once the beneficiary pays the fee for transferring ownership (thirty per cent of the land's market value as set by the department at the time of transfer). ${ }^{16}$ Thus the owner enjoys all powers under the right to property: use, exploitation and disposition. This is undoubtedly important because it contributes to achieving free transfer of real property and, in turn, achieving sustainable development.

\subsection{Real Property Registration}

Law no. (7) of 2006, Concerning Real Property Registration in the Emirate of Dubai, regulates the registration of real property rights and long-term leasehold contracts, through the creation of a property register that will record all real property rights and any amendments thereto. ${ }^{17}$ This property register has absolute evidentiary value against all parties, and the validity of its data may not be impugned, unless it is proven to be the result of fraud or forgery. All transactions that create, transfer, amend or extinguish real property rights must be recorded in the register. Final rulings validating such transactions must also be recorded. Such transactions will not be deemed valid unless recorded in the property register. Furthermore, any agreement or disposition in breach of the provisions of this law, or made with the intention of circumventing them, will be deemed null and void. The department issues title deeds relating to real property rights based on the data in the register. Those title deeds will have absolute evidentiary value in verifying real property rights. ${ }^{18}$

Law no. (13) of 2008, Regulating the Interim Property Register in the Emirate of Dubai, regulates the legal dispositions made over real property units that are sold off-plan. ${ }^{19}$ Real property units that are specified as off-plan, or that are under construction or partially constructed, can be disposed of. A real property register, the 'Interim Property Register', has been created, in which all dispositions made over real property units sold off-plan must be recorded. Failing to do so deems the dispositions null and void..$^{20}$ Buyers of real property units

16 Ibid., Arts. 2-4. Furthermore, under Art. 5, the occupier of allotted land, which has been transferred to him by way of sale, may request that title to the allotted land be granted him on a freehold basis, without any restriction. If the department approves this request and the occupier pays the ownership transfer fee (fifty per cent of the land's market value), title to the allotted land will be granted to the occupier.

17 Law No. 7 of 2006, Concerning Real Property Registration in the Emirate of Dubai.

18 Ibid., Arts. 6, 7, 9, 26, 22 and 24.

19 Law No. 13 of 2008, Regulating the Interim Property Register in the Emirate of Dubai.

20 Ibid., Art. 3. 
can dispose of them by way of sale, mortgage or any other legal disposition. ${ }^{21}$ Therefore, UAE legislators permit the disposing of the subject matter of the contract (i.e. a real property unit) even though it still does not exist - in order to dispose of the subject matter of the contract, it suffices that it will exist in the future. However, to avoid the possibility of fraud or deception, sellers are advised to require buyers to pay the price in full, which fact entitles him to dispose of the off-plan real property unit.

UAE legislators have legally protected buyers of off-plan real property units, by preventing master developers and sub-developers from starting a project or disposing of their real property units by way of off-plan sale, unless they have taken possession of the land on which the project will be implemented, and have obtained the required approvals from the competent entities in the emirate. Any contract entered into prior to obtaining such approvals will be null and void..$^{22}$ In order to boost the off-plan buyer's confidence, UAE legislators have confirmed that, if, after delivery of a unit, there is any increase in the value of the area in which the real property unit sits, the developer may not claim any increase in price in consideration for such increased value, but if a decrease in the value of the area occurs, then the developer must compensate the buyer for such decrease, unless such decrease is inconsequential. ${ }^{23}$

Based on the above, it is clear that buyers of real property units are sufficiently protected by law. UAE legislators have deemed the contract of sale of a real property as a merely formal one that is only valid if it is registered with the Land Department. This approach is not prevalent in other jurisdictions, as they deem the contract of sale of a real property to be a consensual one that is held valid upon mutual consent, without having to follow a particular form of contract. No doubt the trend of the UAE legislators is worthy, as it protects buyers against fraud and deception and further boosts their confidence in a sale transaction that is made under official procedures, by a competent employee

21 Ibid., Art. 6.

22 Ibid., Arts. 4 and 10. Under Art. 2, 'master developer' is defined as any person licensed to engage in the real estate development business and the sale of real property units to third parties in the emirate; 'sub-developer', as any person licensed to engage in the real estate development business and the sale of units to third parties and who undertakes part of the real estate development project of a master developer in accordance with a mutual agreement.

23 Ibid., Art. 12. According to Art. 13(3) of Executive Council Resolution No. 6 of 2010 Promulgating the Executive Regulations of Law No. 13 of 2008 on Regulation of the Interim Property Register, such decrease is deemed inconsequential if it does not exceed five per cent of the net area of the real property unit. 
who has all the data relating to the project and the real property unit, and the price is paid and the unit is registered in the property register.

Providing even more protection to the buyer, once the development project is completed and the completion certificate has been obtained from the competent entities, the master developer or sub-developer must hand over and register the real property unit in the buyer's name in the property register, provided that the buyer has fulfilled all contractual obligations. If the master developer or sub-developer refuses to do so, the Land Department may, upon the buyer's request or upon its own initiative, register the real property unit in the buyer's name in the property register. ${ }^{24} \mathrm{UAE}$ legislators have thus conferred broad authority on the Land Department, to the extent that it can register real property units in the property register without a court decision, a matter that is not prevalent in relevant general legal rules.

UAE legislators have also created the Real Estate Regulatory Agency (RERA) under Law No. (16) of $2007 \cdot{ }^{25} \mathrm{RERA}$ is a public agency entrusted with regulating the real estate sector in the emirate and preparing related strategies, including proposing real estate legislations, issuing regulatory bylaws, licencing all real estate development activities, accrediting financial institutions that are qualified to manage real estate development escrow accounts, and licencing, regulating and monitoring real estate brokerages. ${ }^{26}$

24 Executive Council Resolution No. 6 of 2010 Promulgating the Executive Regulations of Law No. 13 of 2008 on Regulation of the Interim Property Register, Art. 7.

25 Under Law No. 16 of 2007.

26 Ibid., Art. 5. To encourage real estate investment, the Land Department created the Real Estate Investment Management and Promotion Center (REIMPC) to serve as its investment arm. The REIMPC supports national and international real estate investment companies and encourages investment to achieve sustainable development. The Land Department also created the Dubai Real Estate Institute (DREI), to serve as its educational arm. The DREI develops the real estate sector by educating, training and raising awareness of market dealers in order to increase their knowledge and improve their performance, through providing more than seventy real estate-related courses, which contributes to raising awareness and, hence, to achieving sustainable development. The Emirates Real Estate Solutions (ERES) is the technical arm of the Land Department. Its objective is to find e-solutions for the real estate market. In addition to the above, a smart application, Registration Trustees (RT), has been launched on smart devices (Android and IOS) to help public users to view all of the RT offices on Dubai Map and read all of the procedure and services details provided by the RT office. The creation of many RT offices in Dubai likely aims to achieve speed in completing real estate transactions, which positively impacts on real estate investment activities. See the Land Department's website: www.dubailand.gov.ae/Arabic/services/smartapplications, accessed 10 June 2016. 


\subsection{Regulating the Work of Real Estate Developers and Brokers}

The UAE's legal framework also regulates the work of real estate developers. No person may engage in real estate development activities without a licence from RERA ${ }^{27}$ and without being listed in the Register of Real Estate Developers (RRED), with the Land Department. A developer may not advertise in local or international media and may not participate in local or international exhibitions, to promote the sale of units or real property off-plan, without written authorization from the Land Department. Whoever engages in a real estate development activity in Dubai, without the required licence, is liable to imprisonment and a fine of at least AED 100,000, or either penalty. The same penalty applies to anyone who provides the competent entities with incorrect documentation or information in order to obtain a licence to engage in real estate development activities. Moreover, a developer who violates any of the laws and bylaws regulating real estate development in Dubai will be struck off the RRED. ${ }^{28}$

UAE legislators have also regulated the work of real estate brokers. No person may engage in real estate brokerage activities in Dubai without a licence from the RERA and a listing in the Register of Real Estate Brokers (RREB). ${ }^{29} \mathrm{~A}$ real estate broker applying for a licence must, inter alia, pass certain real estate courses and pass the Brokerage Test prepared by RERA. A real estate broker must also disclose all negotiation details to clients, as well as the stages of the brokerage process and other core areas relating to the subject matter of the contract, and is liable for any loss or damage suffered by the contracting parties as a result of his fraudulent act or deceit. ${ }^{30}$

Under UAE law, if a number of real estate brokers are involved in one contract, they will be jointly liable to the client. ${ }^{31} \mathrm{~A}$ client who enters into a contract with multiple brokers can ask any of them for full compensation for damage; brokers cannot argue that compensation should be divided among them. The buyer's right is fully guaranteed against all brokers. Moreover, if any of the brokers are declared bankrupt, the other brokers are liable to pay his share of the compensation. To avoid fraud or deception, and to achieve confidence, UAE legislators have decided that a real estate broker is entitled to

27 The RERA was established under Law No. 16 of 2007. Art. 5 lists RERA's powers, including that to license real estate development activities in Dubai.

28 See Law No. 8 of 2007, Concerning Escrow Accounts for Real Estate Development in the Emirate of Dubai, Arts. 4, 5, 16 and 17.

29 Bylaw No. 85 of 2006 , Art. 3.

$30 \quad$ Ibid., Art. 6; see also Arts. 17 and 22.

31 Ibid., Art. 24, since it cannot be automatically supposed, but, rather, must be adopted, whether by a mutual agreement or a law. 
remuneration only after signing a contract of sale and registering it with the Land Department, unless the brokerage agreement stipulates otherwise. ${ }^{32} \mathrm{UAE}$ legislators also require real estate developers to deal only with real estate brokers listed in the RREB; otherwise, they will be liable to imprisonment and a fine of at least AED 100,000, or either penalty. ${ }^{33}$

The above shows that the law aims to boost investors' confidence by setting controls that define the work of real estate developers and brokers; by providing precise, effective legal protection to encourage real estate investment; and by standing firmly against anyone who wrongly interferes with the requirements of real estate activities. ${ }^{34}$

\subsection{Escrow Accounts for Real Estate Development}

Law no. (8) of 2007, Concerning Escrow Accounts for Real Estate Development in the Emirate of Dubai, regulates the sale of off-plan units in real estate development projects in Dubai, and the receipt of payments from buyers or financers against such units, are also regulated. ${ }^{35}$ This Law requires any developer who wishes to sell off-plan units to apply to the Land Department to open an escrow account for the project, into which it must deposit payments made by off-plan buyers or by the project's financers. Once the Land Department approves the application, an escrow account is opened, under a written agreement made between the developer and the escrow agent recognized by the department. Accordingly, all payments made by the buyers and financers will be deposited with the escrow account. This agreement determines how the escrow account is managed, and a copy of it must be submitted to the department. The deposits must be spent only on the construction of the real estate project, and no attachment may be imposed thereon for the benefit of the developer's creditors. The Land Department monitors the account; the escrow agent must regularly provide the department with statements of the account's revenue and expenditure. In the event of emergency when the real estate

\section{$32 \quad$ Ibid., Art. 28.}

33 Law No. 8 of 2007, Concerning Escrow Accounts for Real Estate Development in the Emirate of Dubai, Art. 16 .

34 In addition, an application has been launched for smart devices, enabling any person to obtain information about licensed brokers and their performance, so that the necessary protection is guaranteed to investors. Another application, 'Mashrooi', has been launched on smart devices, giving information about the developers admitted by the Land Department and the projects existing in Dubai, in terms of the place, type, completion percentage and escrow account of each project. See the Land Department's website, www.dubailand.gov.ae/Arabic/services/smartapplications, accessed 10 June 2016.

35 Law No. 8 of 2007, Concerning Escrow Accounts for Real Estate Development in the Emirate of Dubai. 
development project is not completed, the project's escrow agent must, after consulting the department, take measures to preserve depositors' rights and ensure either that the real estate development project is completed or that depositors are refunded. Even once the developer obtains the completion certificate, escrow agents must retain five per cent of the total value of each escrow account. The escrow agent releases this retained amount to the developer one year after the units are registered in the buyers' names. Anyone who knowingly offers units in a fraudulent real estate development project for sale, or steals, appropriates or forfeits any amounts of money delivered to them for the purpose of implementing a real estate development project, is liable to imprisonment and a fine of at least AED 100,000, or either penalty. ${ }^{36}$

The UAE's legislators provide precise and comprehensive legislative protection to real estate buyers and investors. This is an example of wise, strategic management that is aimed at achieving sustainable development.

\subsection{Regulating the Tenancy of Property}

Law No. (33) of 2008, Amending Law No. (26) of 2007, Regulating the Relationship between Landlords and Tenants in the Emirate of Dubai, regulates the lease of properties intended for housing, commercial business, certain crafts or professions and any other legitimate activity are also regulated in Dubai. ${ }^{37}$ The law includes precise provisions on how the relationship between landlords and tenants is regulated. Landlords are given the right to evict tenants from real property in the event that the tenants violate their contractual obligations. ${ }^{38}$ The percentages by which property rents can increase when leases are renewed are also regulated, ${ }^{39}$ and are linked to the average rent of similar units, according to the RERA Dubai Rent Index. ${ }^{40}$

The Rent Disputes Settlement Centre (RDSC) in Dubai, is headquartered at the Land Department and may establish other offices in the emirate. ${ }^{41}$ It has exclusive jurisdiction to resolve all rent disputes that arise between landlords and tenants of real property situated in Dubai. ${ }^{42}$ The RDSC is intended to be a specialized judicial system that expeditiously and simply decides on rent

$36 \quad$ Ibid., Arts. 6, 7, 9, 11, 14, 15 and 16.

37 Law No. 33 of 2008, Amending Law No. 26 of 2007 , Regulating the Relationship between Landlords and Tenants in the Emirate of Dubai.

$38 \quad$ Ibid., Art. 25.

39 Decree No. 43 of 2013, Determining Rent Increases for Real Property in the Emirate of Dubai, regulates this.

$40 \quad$ Ibid., Art. 1.

41 It was established under Decree No. 26 of 2013.

42 Ibid., Arts. 3 and 6. 
disputes, all for the purpose of realizing social and economic stability for all persons involved in the real property rental sector and, in turn, achieving sustainable development. In addition, the UAE's legislators have created a special tribunal for the settlement of check disputes relating to real estate transactions, under Decree No. (56) of 2009. This tribunal has exclusive jurisdiction to settle complaints related to dishonoured checks issued by a buyer for the benefit of a real estate developer or by a usufructuary or a tenant. ${ }^{43}$

The UAE's legislators are thus keen to provide safe investment opportunities to investors in real estate leases. They guarantee the owners a stable annual percentage of profit or recovery through precise legal rules regulating the increase in the rent of property. Further, they provide an easy means for knowing about rents, property for rent and all other relevant matters.

\section{4 \\ The Real Estate Legislative System's Impact on Sustainable Development}

The UAE's real estate laws relating to the right to property, the work of real estate developers and brokers, procedures for registering real property, transfer of ownership, leasing of property and all other relevant matters have clearly and concretely impacted on the country's sustainable development indicators. This is evident in the UAE's rankings in various major global development indicators, most notably the Human Development Index (HDI) of the UNDP's Human Development Report, and the Ease of Doing Business Index of the World Bank's 'Doing Business Report'.

The UAE's real estate laws are among the basis of its sustainable development legal system. They demonstrate the UAE's adherence to the Declaration on the Right to Development (1986), especially Article 10, which states that steps should be taken to ensure the full exercise and progressive enhancement of the right to development, including the formulation, adoption and implementation of policy, and legislative and other measures at the national and international levels. The UAE's real estate laws embody, to a high degree, Article 17 of the Universal Declaration of Human Rights, which states that everyone has the right to own property alone, as well as in association with others. As

43 Moreover, a smart application, 'Ejari', has been launched on smart devices, providing services to tenants and owners in the rental sector, including a rental index calculator, approved management companies and their locations, and licenced typing centres, for registering tenancy contracts. The Ejari application is a smart, integrated system that owners and property management companies can use. See the Land Department's website: www.dubailand.gov.ae/Arabic/about/aboutdld, accessed 10 June 2016. 
mentioned above, these real estate laws grant the right to property to any individual, whether citizen or foreigner, contrary to the laws of many other countries, which restrict property ownership.

Real estate laws, as well as government measures and regulations relating to the licencing and activities of businesses in any economy, are among the most influential variables affecting economic growth and, in general, macroeconomic indicators. Furthermore, they play a crucial role in a country's investment climate, and attract leading projects. Hence private sector activities, and the dynamism and effectiveness of the sector's role in the economy, are significantly affected by procedures and regulations governing business activitiesincluding those regulating property rights and property rental (as well as by business costs, in terms of the fees and expenses borne by businesses when procuring certain activity licences, especially SMEs — see Table 1 ).

The development plans, as well as governmental legislation, actions and policies that have been set and taken over recent years in the UAE have impacted positively on its position in global development rankings: In fact, the UAE has been ranked highly in various world development indicators. Table 1 shows the UAE's most prominent development indicators, according to the latest Human Development Report (2015). As can be seen from the table, the UAE's Human Development Index (HDI) score was 0.835 (and the UAE was ranked 41st globally), which falls within the Very High Human Development category.

The HDI recorded a growth of $0.59 \%$ (1990-2014), which is higher than the global average for the Very High Human Development category ( $0.47 \%)$ during the same period. The UAE's 'Life Expectancy at Birth' indicator stood at 77 years, compared to 80.5 years for the Very High Human Development category (to which the UAE belongs), and 70.6 years in Arab countries (see Fig. 1). This shows the UAE's significance and ability to attract foreign direct investment (FDI): net FDI inflows stood at 2.6\%, compared to 1.9\% for the Very High Human Development category and an average of $1.7 \%$ in Arab countries.

The legal system has a direct impact on the business environment of the country, ${ }^{44}$ as is shown by the 'Doing Business Report', ${ }^{45}$ a World Bank report

44 All definitions and terms mentioned in this study related to the set of 'Doing Business' sub-indicators are based on the methodology adopted in the 2016 'Doing Business Report', available at www.doingbusiness.org.

45 The 'Doing Business Report' measures how rules and regulations impact on business activities. It provides objective measures of the nature of such government actions and regulations and related costs. In the Ease of Doing Business Index, the countries are ordered from 1 to 189 , from best to worst, in terms of ease of doing business. A country's ranking signifies to what extent its regulatory environment is appropriate and how easy it 


\begin{tabular}{ll}
\hline Indicator & Value \\
\hline Human Development Index (HDI) & 0.835 \\
HDI Rank & 41 \\
Category of Rank & Very High Human Development \\
Life Expectancy at Birth & 77 \\
Expected Years of Schooling & $13 \cdot 3$ \\
Mean Years of Schooling & $9 \cdot 5$ \\
Gross National Income (GNI) Per Capita & $60,868 \mathrm{PPP}(2011)$ \\
Net Foreign Direct Investment (\% of GDP) & $2.6 \%(2013)$ \\
& \\
\hline
\end{tabular}

SOURCE: UNITED NATION DEVELOPMENT PROGRAM “UNDP”. HUMAN DEVELOPMENT REPORT 2015. www.undp.org/

that aims to provide an objective basis for understanding and improving the regulatory environment for business around the world.

The report covers 11 sets of indicators in 189 countries, 10 of which are related to the ease of doing business. ${ }^{46}$ The last set measures the regulation of the labour market. This means that real estate laws are among the key indicators that reflect the ranking of the country in terms of ease of doing business there and, in turn, the extent to which it can attract both local and foreign investors. Those laws are directly reflected in various sets of indicators covered by the 'Doing Business Report', especially in the registering of property.

Dubai was the city chosen for the UAE's ranking in the report. ${ }^{47}$ Hence the UAE's rankings in all indicators of the report are based on the laws, rules and procedures that are applicable in Dubai. According to the 2016 report, the UAE's ranking has improved to 31 out of 189 in terms of ease of doing business, up from 32nd in 2015. In the Middle East and North Africa region (MENA), the UAE ranked 1st out of 20 countries in this category.

is to establish and manage a local company or SME. The countries are ordered by measuring the Distance to Frontier (DTF), in terms of 10 themes. Each theme comprises several indicators; all themes are weighted equally.

46 Starting a Business, Dealing with Construction Permits, Getting Electricity, Registering Property, Getting Credit, Protecting Minority Investors, Paying Taxes, Trading Across Borders, Enforcing Contracts and Resolving Insolvency.

47 The city covered in the 'Doing Business Report' 2016 is Dubai. 


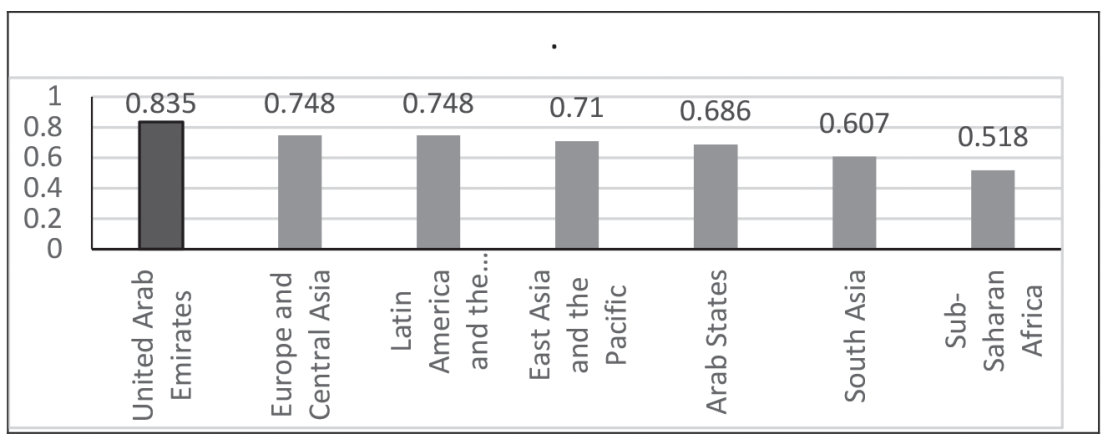

FIGURE 1 HDI value of the UAE compared to countries of the world, 2015 SOURCE: WORLD BANK GROUP, DOING BUSINESS REPORT 2016. www.doingbusiness.org

The UAE ranked 28th out of 60 countries regarding the high-income category to which it belongs, ranking higher than such countries such as Spain, Japan, Italy, Russia, Argentina, Venezuela, Israel (that ranked 39th in the high-income category and 53rd at the global level) and others (see Table 2).

Concerning the UAE order in the Doing Business Report at the level of subsets and sub-indicators, Table 3 shows the changes in the UAE's rankings in the ten 'ease of doing business' sets of indicators. Our focus will be on the sets of indicators related to real estate laws.

At the level of starting a business, ${ }^{48}$ the UAE ranked 6oth globally out of 189 economies, and second among MENA countries (see Table 4). A great achievement can be noted in terms of the ease of starting a business, which is one of the bases for the developmental process. The sub-indicators that measure the ease of starting a business (see Table 4) reveal that relatively low levels of bureaucracy, time and cost are required for establishing an SME (i.e. a business activity) in Dubai, it needs only 6 procedures and takes only 8 days, whereas 18.8 days are needed in MENA countries, and 8.3 days in OECD countries.

48 'Doing Business records all procedures officially required, or commonly done in practice, for an entrepreneur to start up and formally operate an industrial or commercial business, as well as the time and cost to complete these procedures and the paid-in minimum capital requirement. These procedures include obtaining all necessary licences and permits and completing any required notifications, verifications or inscriptions for the company and employees with relevant authorities'. See the World Bank's website: http:// www.doingbusiness.org/Methodology/starting-a-business, accessed 10 June 2016. 


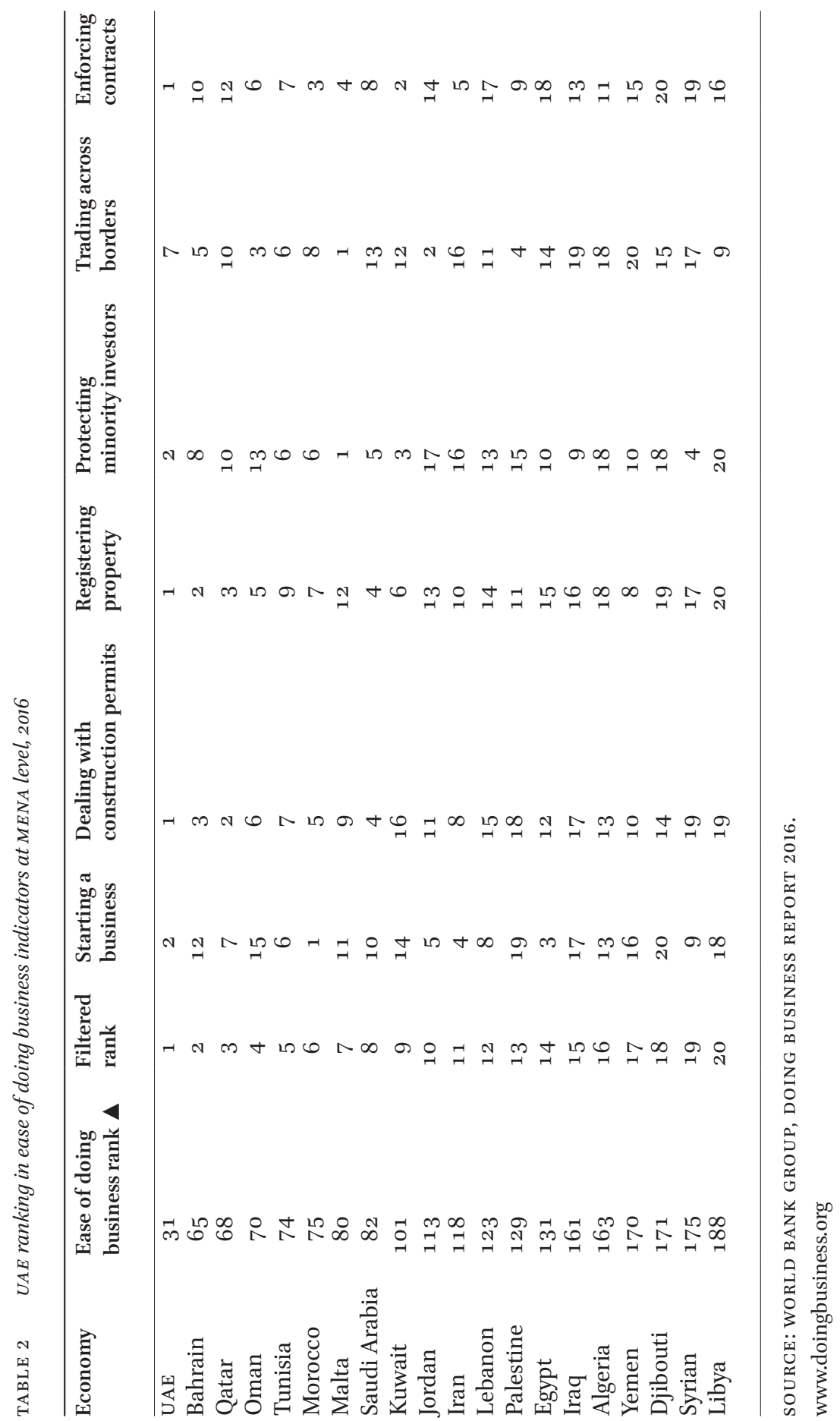




\begin{tabular}{lrrl}
\hline Starting a Business & 57 & 60 & -3 \\
Dealing with Construction Permits & 3 & 2 & 1 \\
Getting Electricity & 4 & 4 & No change \\
Registering Property & 10 & 10 & No change \\
Getting Credit & 90 & 97 & -7 \\
Protecting Minority Investors & 64 & 49 & 15 \\
Paying Taxes & 1 & 1 & No change \\
Trading Across Borders & 101 & 100 & -1 \\
Enforcing Contracts & 18 & 27 & 9 \\
Resolving Insolvency & 91 & 90 & -1 \\
& & & \\
\hline
\end{tabular}

SOURCE: WORLD BANK GROUP, DOING BUSINESS REPORT 2016. www.doingbusiness.org

TABLE 4 UAE's 'Starting a Business'sub-indicators, 2016

\begin{tabular}{llcl}
\hline Indicator & UAE & MENA & OECD high income \\
\hline Procedures (number) & 6 & 8.2 & 4.7 \\
Time (days) & 8 & 18.8 & 8.3 \\
Cost (\% of income per capita) & 6.2 & 25.8 & 3.2 \\
Paid-in min. capital (\% of income & 0 & 37.7 & 9.6 \\
per capita) & & &
\end{tabular}

SOURCE: WORLD BANK GROUP, DOING BUSINESS REPORT 2016.

www.doingbusiness.org

As to the paid-in minimum capital (recorded as a percentage of income per capita), the UAE stood at $0 \%$, compared to $37.7 \%$ and $9.6 \%$ in MENA and OECD countries respectively. The ease, speed and cost-effectiveness of procedures reflects the UAE's legal system's flexibility and modernity, particularly Dubai's.

A relative decrease in cost (recorded as a percentage of income per capita) can also be noted while establishing a simple enterprise- $-6.2 \%$ of the average national income per capita in the UAE, compared to $25.8 \%$ in MENA countries and $3.2 \%$ in OECD countries. 


\subsection{The Set of 'Dealing with Construction Permits' Indicators}

At the level of 'Dealing with Construction Permits', ${ }^{49}$ the UAE ranked 2 nd globally and ist among MENA countries, an inevitable reflection of the vitality and flexibility of real estate legislation in Dubai compared to other global cities (see Table 5).

As for the 'Dealing with Construction Permits' sub-indicators, the number of procedures necessary for dealing with a construction permit in the UAE is only 8, compared to about 14.8 in MENA countries and 12.4 in OECD countries. These procedures take about only 43.5 days in the UAE, compared to 139.7 days and 152.1 days in MENA and OECD countries respectively. The cost of construction procedures in the UAE is relatively low (only $0.2 \%$ of income per capita), compared to $3.1 \%$ and $1.7 \%$ in MENA and OECD countries respectively. The building quality control index in Dubai stands at 11, which is better than MENA countries (9.5) and very close to OECD countries (11.4) (the top of the scale is 12).

TABLE 5 UAE's 'Dealing with Construction Permits'sub-indicators, 2016

\begin{tabular}{lrcc}
\hline Indicator & UAE & $\begin{array}{l}\text { Middle East \& } \\
\text { North Africa }\end{array}$ & $\begin{array}{l}\text { OECD high } \\
\text { income }\end{array}$ \\
\hline Procedures (number) & 8.00 & 14.8 & 12.4 \\
Time (days) & 43.50 & 139.7 & 152.1 \\
Cost (\% of warehouse value) & 0.20 & 3.1 & 1.7 \\
Building quality control index (0-15) & 11.00 & 9.5 & 11.4 \\
\hline
\end{tabular}

SOURCE: WORLD BANK GROUP, DOING BUSINESS REPORT 2016.

www.doingbusiness.org

49 'Doing Business records all procedures required for a business in the construction industry to build a warehouse along with the time and cost to complete each procedure. In addition, this year Doing Business introduces a new measure, the building quality control index, evaluating the quality of building regulations, the strength of quality control and safety mechanisms, liability and insurance regimes, and professional certification requirements. Information is collected through a questionnaire administered to experts in construction licensing, including architects, civil engineers, construction lawyers, construction firms, utility service providers and public officials who deal with building regulations, including approvals, permit issuance and inspections'. See the World Bank's website: http://www.doingbusiness.org/data/exploretopics/dealing-with-constructionpermits/faq\#1, accessed 10 June 2016. 


\subsection{The Set of 'Registering Property' Indicators}

One of the main themes in the 'Doing Business Report' is the ease of registering property, which is considered the core of real estate laws, as explained earlier in this article. The report lists the full sequence of the procedures required for a business (i.e. a buyer) to buy a real property from another business (i.e., a seller) and, hence, to transfer the real property thereto, so that the buyer can expand its business activities, use it as a real guarantee against new loans or, if necessary, sell it to another business.

The report calculates the time and cost necessary for each procedure. The 2016 report adds a new measure to the set of 'Registering Property' indicators, namely an index of the quality of the land administration system in each economy. The quality of land administration index has four dimensions: reliability of infrastructure, transparency of information, geographic coverage and land dispute resolution.

The UAE ranked 1oth globally and first among MENA countries in registering property, reflecting the quality and flexibility of real estate laws in Dubai. As to the 'Registering Property' sub-indicators, the number of procedures ${ }^{50}$ necessary for registering a property in the UAE is only 2, compared to an average of 5.7 and 4.7 in MENA and OECD countries respectively. These procedures take only 1.5 days ${ }^{51}$ in the UAE, compared to 29.6 days and 21.8 days in MENA and oECD countries respectively. The $\cos ^{52}$ of registering a property in the

50 'A procedure is defined as any interaction of the buyer or the seller, their agents (if an agent is legally or in practice required) or the property with external parties, including government agencies, inspectors, notaries and lawyers. Interactions between company officers and employees are not considered. All procedures that are legally or in practice required for registering property are recorded, even if they may be avoided in exceptional cases. It is assumed that the buyer follows the fastest legal option available and used by the majority of property owners. Although the buyer may use lawyers or other professionals where necessary in the registration process, it is assumed that the buyer does not employ an outside facilitator in the registration process unless legally or in practice required to do so'. See the Doing Business Report 2016, World Bank's website: http://www .doingbusiness.org/ /media/WBg/DoingBusiness/Documents/Annual-Reports/English/ DB16-Full-Report.pdf, accessed 10 June 2016.

$5^{1}$ 'Time is recorded in calendar days. The measure captures the median duration that property lawyers, notaries or registry officials indicate is necessary to complete a procedure. It is assumed that the minimum time required for each procedure is one day, except for procedures that can be fully completed online, for which the time required is recorded as half a day. Although procedures may take place simultaneously, they cannot start on the same day, again with the exception of procedures that can be fully completed online'. Ibid. 'Cost is recorded as a percentage of the property value, assumed to be equivalent to 50 times income per capita. Only official costs required by law are recorded, including 
UAE is relatively low ( $0.2 \%$ of the property value), compared to $5.6 \%$ and $4.2 \%$ in MENA and OECD countries respectively (see Table 6).

The UAE scored 20 as to the quality of the land administration index (0-30 scale), better than MENA countries (12.5) but worse than OECD countries (22.7). In general, this index reflects the flexibility, comprehensiveness and practicality of real estate legislations in Dubai. It is worth mentioning that the quality of land administration index of information has four dimensions: reliability of infrastructure, transparency, geographic coverage and land dispute resolution. Data are collected for each economy's largest business city (in the case of the UAE, Dubai). The four indicators are directly related to the real estate laws and procedures for registering a property in the country. The 'Quality of Land Administration' index is measured as the sum of the scores on the four indicators. The index ranges from o to 6 , with higher values indicating greater transparency in the land administration system.

\subsection{Improvement of the UAE's Ranking over Time}

As to the development of the UAE's ranking between 2010 and 2016, based on the Distance to Frontier (DTF) measure, ${ }^{53}$ we can realize improvement over

TABLE 6 UAE's 'Registering Property' sub-indicators, 2016

\begin{tabular}{llll}
\hline Indicator & UAE & $\begin{array}{l}\text { Middle East \& } \\
\text { North Africa }\end{array}$ & $\begin{array}{l}\text { OECD } \\
\text { high income }\end{array}$ \\
\hline Procedures (number) & 2.00 & 5.7 & 4.7 \\
Time (days) & 1.50 & 29.6 & 21.8 \\
Cost (\% of property value) & 0.20 & 5.6 & 4.2 \\
Quality of the land administration & 20.00 & 12.5 & 22.7 \\
index (o-30) & & & \\
\end{tabular}

SOURCE: WORLD BANK GROUP, DOING BUSINESS REPORT 2016.

www.doingbusiness.org

fees, transfer taxes, stamp duties and any other payment to the property registry, notaries, public agencies or lawyers. Other taxes, such as capital gains tax or value added tax, are excluded from the cost measure. Both costs borne by the buyer and those borne by the seller are included. If cost estimates differ among sources, the median reported value is used'. Ibid.

53 'The distance to frontier score aids in assessing the absolute level of regulatory performance and how it improves over time. This measure shows the distance of each economy 


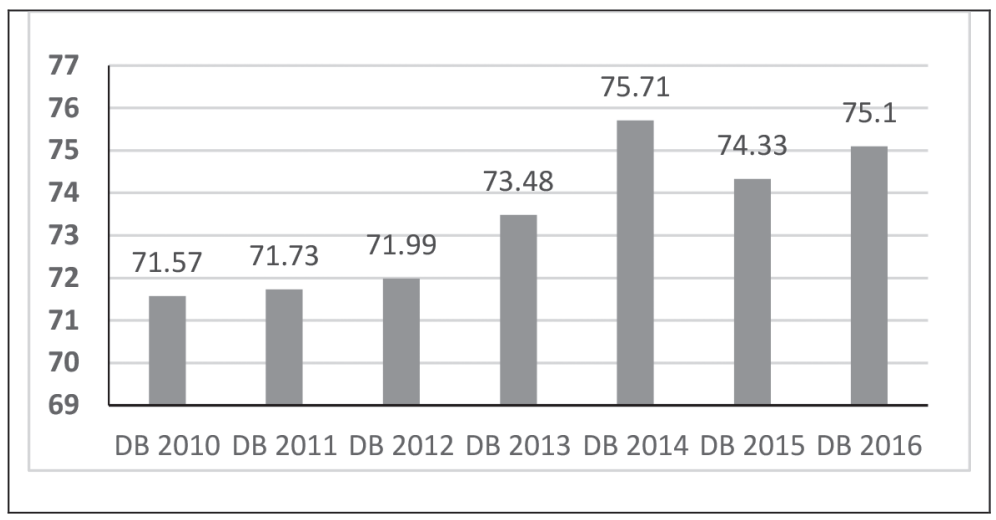

FIGURE 2 UAE DTF measure, 2010-2016

SOURCE: WORLD BANK GROUP, DOING BUSINESS REPORT 2016.

www.doingbusiness.org

time, as the UAE came close to the best DTF, increasing from 71.57 (2010) to 75.10 (2016). This means that the UAE economy is only 24.9 percentage points behind the best DTF in all economies, compared to 28.25 percentage points in 2010 (see Fig. 2).

\section{5}

\section{Conclusion}

This study has shown that the UAE's legislators are keen to regulate the ownership of real property under federal laws. In Dubai, in particular, the legislators have paid attention to the ownership of real property and have enacted many

to the "frontier," which represents the best performance observed on each of the indicators across all economies in the Doing Business sample since 2005. This allows users both to see the gap between a particular economy's performance and the best performance at any point in time and to assess the absolute change in the economy's regulatory environment over time as measured by Doing Business. An economy's distance to frontier is reflected on a scale from 0 to 100 , where o represents the lowest performance and 100 represents the frontier. For example, a score of 75 in Dв 2015 means an economy was 25 percentage points away from the frontier constructed from the best performances across all economies and across time. A score of 80 in Dв 2016 would indicate the economy is improving. In this way the distance to frontier measure complements the annual ease of doing business ranking, which compares economies with one another at a point in time'. Ibid. 
laws and regulations and created several institutions to encourage investment in real estate activities. They have also provided various legal protections to real estate investors. For example, the protection given to the buyer of a real unit, as the law deems the contract of sale of a real property as a merely formal one that is not valid unless it is registered with the Land Department, a matter that is not prevalent in other legislations. This approach boosts a buyer's confidence in a sale made under official procedures by a competent employee who has all the data relating to the project and the real property unit, while having the price paid in conjunction with registration of the unit in the property register.

The UAE's legislators have conferred broad authority on the Land Department so that it can register the real property unit in the property register without needing a court decision, if the developer refrains from making such registration. They have further set controls that define the work of real estate developers and brokers, providing the precise, effective legal protection that is necessary for encouraging real estate investment, and standing firmly against anyone who wrongly interferes with the requirements of real estate activities. Accordingly, many acts that might destabilize real estate investment have been criminalized. The UAE's legislators are also keen to establish a specialized judicial system, which, through an expeditious and simple process, decides on rent disputes, for the purpose of realizing social and economic stability for all persons involved in the real property rental sector and, in turn, achieving sustainable development. They guarantee the owners a stable annual percentage of profit or recovery through precise legal rules regulating rent increases. They protect the right to property that is granted to any individual, whether citizen or foreigner, which is inviolable, save for some exceptions as prescribed by law. This protection should guarantee sustainable development.

The legal system-particularly real estate laws and property registration procedures - and its great flexibility (in terms of the rights granted to foreigners) have significantly enhanced sustainable development in the UAE and have enabled the UAE's economy to attract foreign investment. This signifies that the UAE legal experience has managed to embody the legislation matrix and use the incentives granted by the laws, procedures and regulations of the UAE, in general, and Dubai, in particular, in fostering the country's growth rate and economic activities. Accordingly, an advanced developmental position can be achieved on the global economic map, as per the UAE facts in international development reports.

Despite the UAE's improved rankings in global development indicators, there is still more to achieve in the field of development, as it is ranked 41st in 
the HDI. Furthermore, its ranking on the set of 'Ease of Doing Business' subindicators needs more effort, in order to reach higher levels, especially in the 'Registering Property' indicator, as it ranked 1oth globally. Hence, the UAE's legislators and decision makers still have to take more action and steps to raise the UAE rankings in various global development indexes, especially those that grow the economy and attract foreign investment, such as 'Ease of Doing Business' indicators. 